\title{
Brief Summary Concerning Strategic Withholding (Nuclear Parsimony)
}

\author{
L. F. Wouters
}

\section{DISCLAIMER}

This report was prepared as an account of work sponsored by an agency of the United States Government. Neither the United States Government nor any agency thereof, nor any of their emplcyees, makes any warranty, express or implied, or assumes any legal liability or responsibility for the accuracy, completeness, or usefulness of any information, apparatus, product, or process disclosed, or represents that its use would not infringe privately owned rights. Reference herein to any specific commercial product, process, or service by trade name, trademark, manufacturer, or otherwise does not necessarily constitute or imply its endorsement, recommendation, or favoring by the United States Government or any agency thereof. The views and opinions of authors expressed herein do not necessarily state or reflect those of the United States Government or any agency thereof.
FEE CEIVE

JAN? 9997

OSTI

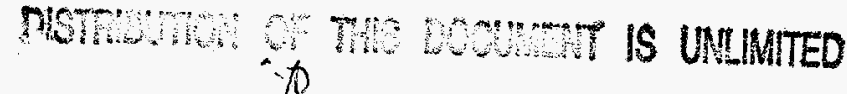

June 2, 1971

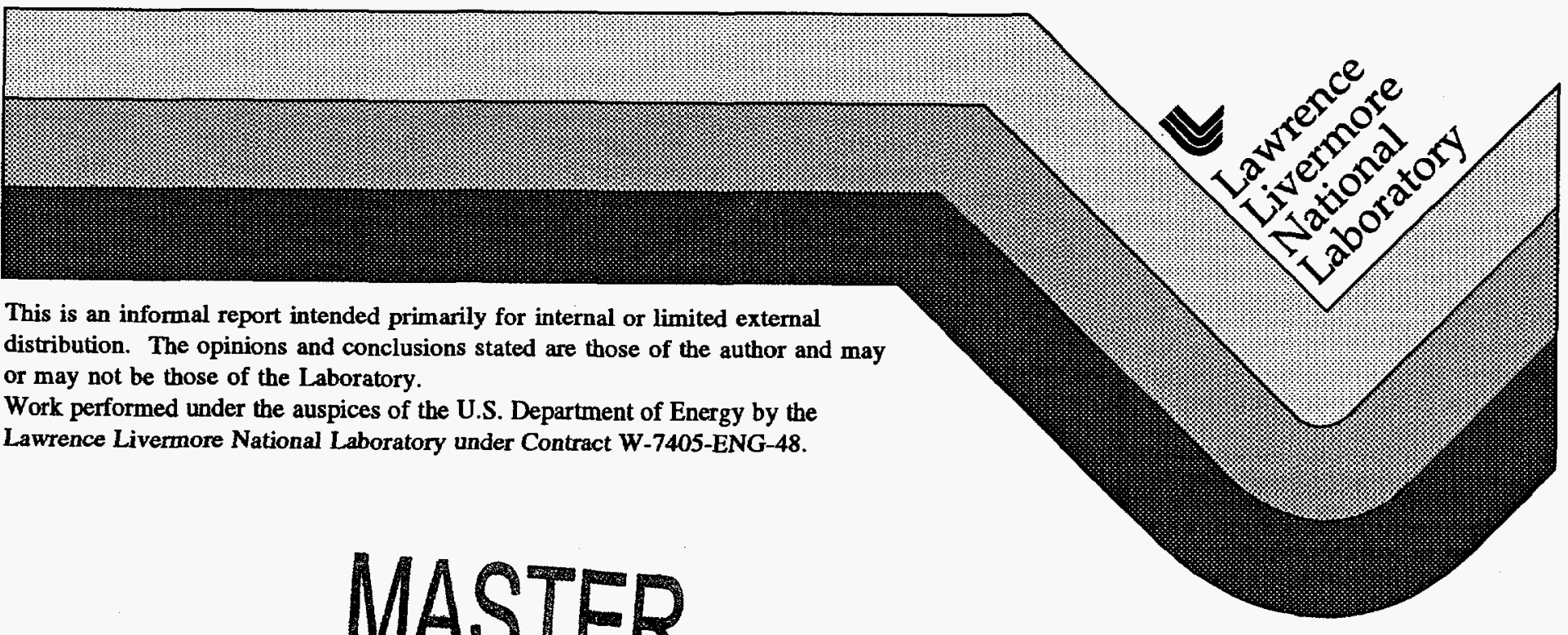




\section{DISCLAMMER}

Portions of this document may be illegible in electronic image products. Images are produced from the best available original document. 

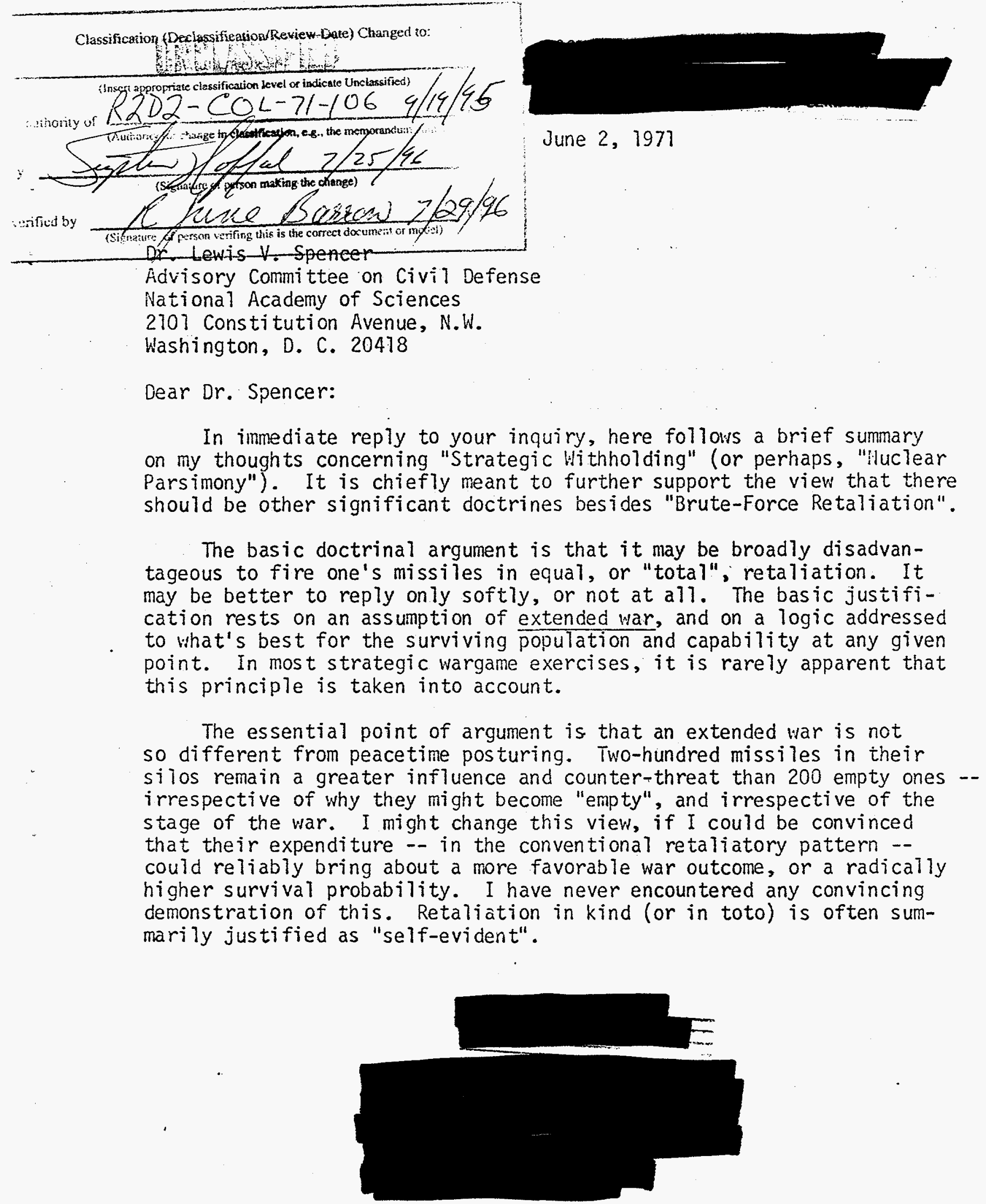
The usual "logical" discussions of strategic propositions are quantitatively quite raw. Sophisticated treatments generaily lead to iines of reasoning so narrowly constrained, as to be easily discredited on grounds of speciousness. This at once also perpetuates "more brute force" as a refuge from risk and uncertainty. In order to further iliustrate the logic here, I too must use raw definitions, assumptions and deductions:

First I make the "one-for-one" assumption: Force parity, and also parity in success of counterforce attack. (Any significantly different circumstance leads to "What's the point?" -- One way or the other.) In a salvo counterforce attack, the aggressor eliminates both his and your forces as significant military elements. Both sides are left with empty holes. If he miscalculates in an important way, there are two possibilities: If he overkills, then our "withholding" makes no difference. If he underkills, then he's got none left, but we've got some "filled holes".

Next, consider the other (unlikely) extreme, the purely countervalue salvo attack. (Quasi-extermination.) A retaliatory value strike only salves the consciences of your dead. It does not revive them, it does not necessarily eliminate anything of later optimum military use, and a posteriori, it militarily reduces you to a par with the aggressor. One really needs to watch the course of the war to evaluate the optimum commitment pattern -- in targets and time -- and this suggests commitment on a parsimonious basis.

Now consider the response to a measured attack -- in other words, in the context of an extended war. Basically what needs continous evaluation, is the levels of relative attrition which can be afforded. In principle, withholding trades your cities and people in return for favorable attrition of the aggressor's strategic forces. That is a very rugged policy to consider, but I will shortly suggest why it may be unavoidabie, in the near future.

The mixed counterforce-countervalue extended war is an intermediate combination of these patterns - - at least on the basis of a simple linear arithmetic. It still favors withholding, because in effect, the (aggressor) countervalue attack capability is reduced more-or-less in the same way as -it would be by disarmament, and to the degree that his missiles are assigned to counterforce missions.

A withholding policy gains significance in a period of armament reduction. Suppose we count one "city" as equivalent to one warhead, and count a country as 200 cities. If both sides have $1000 \mathrm{w} / \mathrm{h}$, there is no contest. If both sides have 200 , withholding can develop a noticeable force differential.

Perhaps the most persuasive case is the multi-nuclear-pact situation. $(n \simeq 4)$ Then the potential penalties on force expenditure can be severe

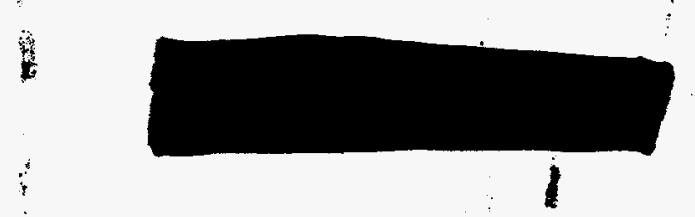


inceed. Frugality becomes dominant; good intelligence and deliberate analysis are indispensable in optimizing force commitment. The war cannot avoid being an extended one, with much political "Dack-door" trading and "siding", and with distressing trade-offs between cities and missile reserves.

Perhaps the most significant counter-reaction that can develop in an extended war, is city evacuation. It is note-worthy that the Soviets make this such a dominant feature of their civil defense plan. In a matter of three days, the worth of countervalue strikes can be radically altered by this conceptually simple action. Having elected a restrained course of combat (i.e., limited counterforce action), one is then finally led back to the original basic concept of nuclear weapon purpose, in terms of military value attacks:

$$
1 \text { Missile } \equiv 10^{3} \text { to } 10^{4} \text { bombers. }
$$

You will also note that I correspondingly say nothing about city hostage coercion, in the sense of the political countervalue threat of "filled holes". That may be a meaningful concept in a peaceful setting, but it rapidly evaporates in a "bloody" war. (Quite aside from the evacuation effect.)

of course these are primitive arguments. They are easily brought to question on such raw technical points as the introduction of Polaris or of ABM. I have a modest collection of such side-notes, which also bear on your broader topic of "How to End Wars"; if and when I get them organized, I will forward a sequel. If this helps to extrude a better doctrinal rationale -- whatever that may be -- it will be a worthwhile sacrifice.

\section{Sincerely,}

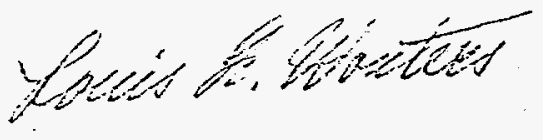

Louis $F$. Wouters

Distribution:

1 of $6 \mathrm{~A}$ - Lewis $V$. Spencer

2 of $6 A$ - Richard Park

3 of $6 \mathrm{~A}$ - James $E$. Carothers

4 of 6 A - Jack N. Shearer

5 of 6 A - Louis F. Wouters (File)

6 of 6 A - Louis F. Wouters (File)

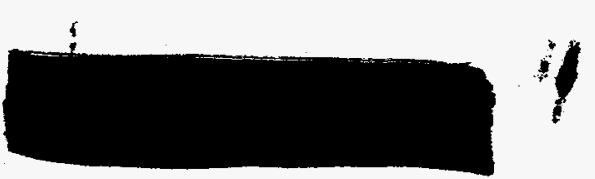

